\title{
A threE YeARS FOLLOW-UP OF TOTAL SERUM IGE LEVELS IN THREE PATIENTS TREATED FOR STRONGYLOIDIASIS
}

\author{
POIRRIEZ J.*
}

\section{Summary :}

A three years follow-up of the level of serum total lgE was made for the first time in three patients with strongyloidiasis after efficient treatment. The decrease of lgE was slow and progressive, showing a logarithmic curve. This regular decrease of total serum lgE could be used as an additional criterion for the evaluation of the efficiency of drug therapy in patients with strongyloidiasis. The persistence of high levels of total lgE two or three years after the elimination of the intestinal parasites, after the return of blood eosinophils to a normal level (within six months), and after the disappearance of specific antibodies, shows that the regulation of the lgE elimination seems to be a complex mechanism.

KEY WORDS : strongyloidiasis, total serum lgE, elimination.
Résumé : Étude de l'Évolution durant trois ans du tauX des IgE SÉRIQUES TOTALES, CHEZ TROIS PATIENTS TRAITÉS POUR ANGUILLULOSE

Chez trois patients traités pour anguillulose et apparemment guéris, une surveillance à long terme des lgE sériques totales a montré une décroissance lente, progressive, suivant une courbe logarithmique. La persistance de taux sériques encore élevés des lgE totales deux ou trois ans après la disparition définitive des parasites intestinaux montre que la régulation de l'élimination des lgE sériques suit des mécanismes probablement complexes et encore peu étudiés.

MOTS CLÉS : anguillulose, IgE sériques totales, élimination.
A t our knowledge, no work has been done on the kinetics and significance of total serum immunoglobulins E (IgE) levels after effective treatment in human helminthiasis, during a long-term follow-up survey. In one study, serum IgE levels were measured only six months after one treatment with thiabendazole in 27 patients with strongyloidiasis (Grove, 1982). So, a prospective study was conducted during three years in three patients treated for strongyloidiasis and who were not exposed to reinfection.

\section{MATERIALS AND METHODS}

\section{PATIENTS AND FOLLOW-UP}

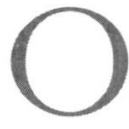
nly three patients with strongyloidiasis were selected, because $i$ ) they showed good compliance and ability to be followed for long time; ii) they were living in the Dunkerque area in good conditions, and they would not have to return to tropical countries during the follow-up; iii) they had left tropical countries for more than 15 years (at least for two patients).

The patients were seen for the first clinical and biological examination, and later were seen twice for the

\footnotetext{
* CIMOT, 4-10, rue Albert Thomas, 59210 Coudekerque-Branche, France.
}

delivery of the treatments. Then, they were carefully examined at six months intervals for one year, and once a year during the two following years.

\section{STOOL EXAMINATIONS}

Parasitological diagnosis of strongyloidiasis was made using three concentration techniques for detection of rhabditiform larvae (L1) of Strongyloides stercoralis in faeces: formalin-ether concentration technique (Ritchie), Baermann extraction technique (Grove, 1989), and Junod combined concentration method (Junod, 1976). These three techniques are referred in this study as complete stool examination.

\section{HAEMATOlOgical TeSTS}

Total white blood cells (WBC) counts and blood eosinophils (BE) levels were measured with a cell-dyn 4000 counter (Abbott).

\section{SEROLOGICAL TESTS}

Total IgE levels in sera of patients were quantitatively measured by automated enzyme-linked fluorescent assay (Vidas). The IgE concentrations were expressed in $\mathrm{IU} / \mathrm{mL}$ (normal under $120 \mathrm{IU} / \mathrm{mL}$ ). It was not possible to analyse specific IgE antibodies. So, along this study, IgE refer to total serum IgE level.

Specific IgG antibodies to $S$. stercoralis were searched (in CHU of Nantes) through an ELISA assay using soluble excretory-secretory antigens obtained from fila- 
riform larvae of S. stercoralis (Northern \& Grove, 1990) (regarded as positive when index $>1$ ). Unfortunately, it was not possible to analyse the last sera from two patients, either because some sera were lost during transport, or for lack of antigen.

\section{CASE REPORTS}

\section{PATIENT $\mathrm{N}^{\circ} 1(\mathrm{C})$}

$\mathrm{P}$ atient $\mathrm{C}$, a 71-year-old man, was born in Zaire in 1925 and had lived there until 1965. Then, he went to Belgium and had not traveled later in any tropical country. He was seen in June 1996 for increased BE count $\left(1,043 / \mathrm{mm}^{3}=13 \%\right.$ of WBC) and IgE level $(568 \mathrm{IU} / \mathrm{mL})$. He told me that he suffered during the previous ten years from cutaneous manifestations suggestive of larva currens, recurring about four times a year; BE were already increased in 1991 $\left(1,500 / \mathrm{mm}^{3}=17 \%\right.$ of $\left.\mathrm{WBC}\right)$; three previous stool examinations were found negative. A complete examination of faeces for parasites gave also negative results in June 1996. A research of specific antibodies to S. stercoralis by ELISA gave strongly positive results in April 1997 (index $=2.06$ ). Blood tests still showed increased levels of $\mathrm{BE}\left(1,070 / \mathrm{mm}^{3}=15 \%\right.$ of WBC) and of $\operatorname{IgE}(777 \mathrm{IU} / \mathrm{mL})$ (Fig. 1C). The patient was asked to eat during three days without fruits and vegetables, and to take a mild laxative (magnesium sulfate, $5 \mathrm{~g}$ per day). The following day, a complete stool examination revealed few $S$. stercoralis L1 larvae. The patient received then two courses of ivermectine (Mec$\operatorname{tizan}^{\circledR}$ ) (two $6 \mathrm{mg}$ tablets at each treatment) on 10.04.97 and on 25.04.97.

\section{PATIENT N ${ }^{\circ} 2($ E)}

Patient E, a 69-year-old man, was born in the French West Indies in 1927. He came to work in northern France in 1952, and went back for one month's holidays in the French West Indies during the years 1983, 1987, 1991, and 1995. I saw him in August 1996, with a typical larva currens on the back. He complained also about diarrhoea (three to four stools per day) and anal pruritus; he showed increased levels of $\mathrm{BE}$ $\left(2,970 / \mathrm{mm}^{3}=37 \%\right.$ of WBC $)$ and of $\operatorname{IgE}(14,300 \mathrm{IU} / \mathrm{mL})$ (Fig. 1E). Patient $\mathrm{E}$ told me that he had recurrent larva currens and diarrhoea since the year 1983. High BE count has been noticed since $1984\left(816 / \mathrm{mm}^{3}=\right.$ $12 \%$ of WBC). IgE were at $585 \mathrm{IU} / \mathrm{mL}$ in 1992 . From 1984 to 1996, ten stool examinations were made without finding any parasite. A complete stool examination led me to recover few L1 larvae of S. stercoralis. Research of specific IgG antibodies to S. stercoralis was found positive (index: 2.21). Patient $\mathrm{E}$ received

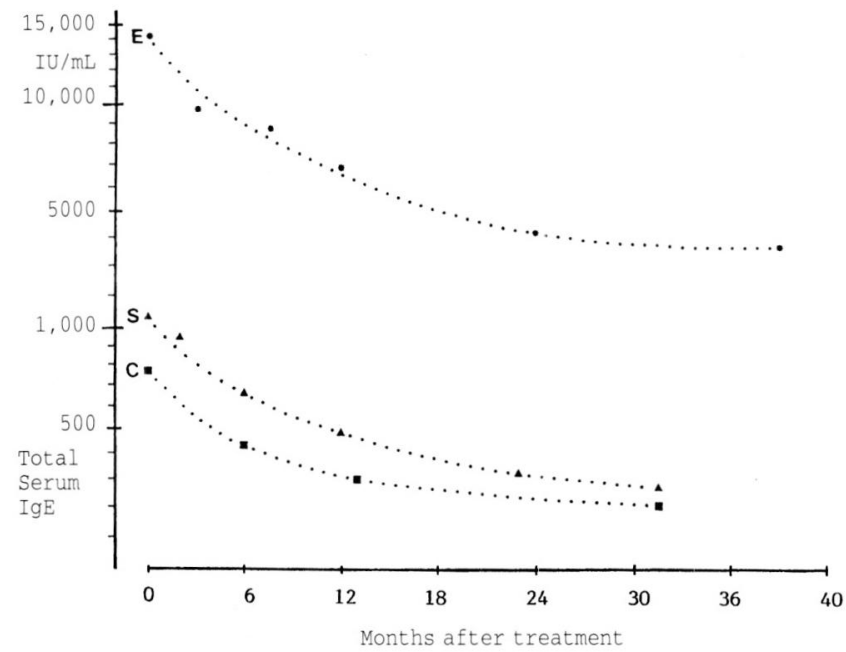

Fig. 1. - Course of total serum IgE levels following treatment, in three patients with strongyloidiasis $(\mathrm{C}, \mathrm{E}, \mathrm{S})$.

first a course of thiabendazole $\left(\right.$ Mintezol $^{\circledR}$ ) (three $500 \mathrm{mg}$ tablets a day on evening, during four days) from 3.09 .96 to 6.09 .96 , and then two courses of ivermectine $\left(\right.$ Mectizan $^{\circledR}$ ) (two 6 mg tablets on 22.09 .96 and on 6.10.96).

\section{PATIENT N ${ }^{\circ} 3(\mathrm{~S})$}

Patient S, a 54-year-old man, was born in Laos in 1942. He left this country in 1979, spent three years in USA, and came in northern France in 1982. I saw him in May 1996 for increased $\mathrm{BE}\left(1,740 / \mathrm{mm}^{3}=21 \%\right.$ of WBC) and $\operatorname{IgE}(1,311 \mathrm{IU} / \mathrm{mL})$ (Fig. 1S), without any clinical manifestation. A complete stool examination showed few L 1 larvae of $S$. stercoralis. Research of specific antibodies to $S$. stercoralis gave strong positive results (index $=2.8$ ). For treatment, he received two courses of thiabendazole (Mintezol ${ }^{\circledR}$ ) (three $500 \mathrm{mg}$ tablets a day on evening during four days) (from 24 to $27^{\text {th }}$ of May, and from 7 to $10^{\text {th }}$ of June), and then one course of ivermectine $\left(\right.$ Mectizan $^{\circledR}$ ) (two $6 \mathrm{mg}$ tablets, on 23.06.96).

\section{RESULTS}

I $n$ the three patients, the increase of the IgE level before treatment was correlated neither with the intensity of the infection (which was light in the three cases), nor with its duration. It is well known that the production of $\mathrm{IgE}$ could vary greatly from a patient to another (Dessaint et al., 1975; Grove, 1982). At the first checkup, six months after treatment, BE had decreased to normal level (under $500 / \mathrm{mm}^{3}$ ) in the three patients; they remained normal through the three years follow-up. No further clinical manifestation was repor- 
ted by the three patients. The complete stool examinations made one year after treatment were negative. Unfortunately, serum antibody assay could be made only for patient $\mathrm{S}$ six months after treatment and gave negative result. All the clinical and biological data collected during the three years follow-up showed clearly that the three patients had been cured of their strongyloidiasis. Furthermore, it was never observed any other pathological event that could have otherwise increased blood eosinophils or IgE level (allergy, drug reaction, auto-immune disease...). Other parasitic infections could also be easily eliminated because each patient has been carefully clinically and biologically examined seven times.

Regarding to the course of the IgE level after treatment, two striking features were noted (Fig. 1). First, their decrease was very slow, their level being still over normal range three years after the treatment which was found otherwise to have been efficient in the three patients. Second, their decrease was progressive and regular, and in the three patients the decay curve showed a characteristic logarithmic form (Fig. 1).

\section{DISCUSSION}

T The treatment of strongyloidiasis is now easy, either with thiabendazole or with albendazole or with ivermectine (Grove, 1989; Poirriez et al., 1994). But none of these drugs is $100 \%$ effective. So, it is recommended to give at least two courses of treatment in immunocompetent patients, either with the same drug or with different drugs. Nevertheless, the remaining difficulty is to be insured that the S. stercoralis infection has been totally eradicated. Stool examinations are not very sensitive (as seen in our patients $C$ and E). Serologic tests could be helpful but are not $100 \%$ sensitive and are not readily available; the lifecycle of S. stercoralis is difficult to establish in animal models and good antigen preparations are not easy to perform. So, the assessment of recovery in strongyloidiasis rests generally on a network of clinical, parasitological, haematological and, when possible, serological arguments. From our work, it is clear that the progressive and logarithmic decrease of total serum IgE could be added to this network.

One striking observation is the contrast between the short life of the IgE antibodies and the very slow decrease of the total serum IgE level despite the removal of the parasitic antigenic stimulation. We know that specific IgE antibodies constitute only a small part (around 10\%) of the total serum IgE level in helminthiasis (Jarrett \& Miller, 1982). In patients with hydatid disease, specific IgE antibodies constitute about $8 \%$ of total serum IgE (Dessaint et al., 1975); and after efficient treatment, specific IgE antibodies decrease to a low level or disappear within six to twelve months (Bekhti et al., 1977). In patients with strongyloidiasis, specific IgE antibodies levels decrease toward zero within also six to twelve months after efficient treatment with ivermectine (Lindo et al., 1996). IgE have a short half-life (three to four days) in serum, but may persist some months in tissues, being binded to surface receptors. If the production and regulation of IgE is beginning to be well understood, far less is known about the mechanisms of IgE elimination (Corry \& Kheradmand, 1999). We have shown for the first time that the elimination of increased total serum $\operatorname{IgE}$ follows a logarithmic curve during several years after the disappearance of the initial stimulating antigen, and after the disappearance of specific IgG and IgE antibodies. It may be possible that IgE could slowly be released from tissular receptors, but larger and more sophisticated studies are necessary to confirm this phenomenon and to understand his mechanisms.

\section{ACKNOWLEDGEMENTS}

I am very grateful to Patrice Le Pape (CHU of Nantes) for measuring the specific IgG antibodies to S. stercoralis by ELISA, although some of the tests could unfortunately not be done.

\section{REFERENCES}

Bekhti A., Schaaps J.P., Capron M., Dessaint J.P., Santoro F. \& CAPRON A. Treatment of hepatic hydatid disease with mebendazole: preliminary results in four cases. British Medical Journal, 1977, 2, 1047-1051.

CORRY D.B. \& KHERADMAND F. Induction and regulation of the IgE response. Nature, 1999, 402 (supplement), B18-B23.

Dessaint J.P., Bout D., Wattre P. \& Capron A. Quantitative determination of specific IgE antibodies to Echinococcus granulosus and IgE levels in sera from patients with hydatid disease. Immunology, 1975, 29, 813-823.

Grove D.I. Treatment of strongyloidiasis with thiabendazole: an analysis of toxicity and effectiveness. Transactions of the Royal Society of Tropical Medicine and Hygiene, 1982, 76, 114-118.

Grove D.I. Strongyloidiasis: a major roundworm infection of man. London : Taylor \& Francis, 1989, 336 p.

JARRETT E.E.E. \& Miller H.R.P. Production and activities of IgE in helminth infection. Progress in Allergy, 1982, 31, 178233.

JunoD CH. Recherche spéciale des œufs et larves d'helminthes dans les selles par la méthode des concentrations combinées. Feuillets de Biologie,1976, 17, 55-62.

Lindo J.F., Atkins N.S., Lee M.G., Robinson R.D. \& Bundy D.A.P. Short report: long-term serum antibody isotype 
responses to Strongyloides stercoralis filariform antigens in eight patients treated with ivermectine. American Journal of Tropical Medicine and Hygiene, 1996, 55, 474-476.

NORTHERN C. \& GROVE D.I. Strongyloides stercoralis: antigenic analysis of infective larvae and adult worms. International Journal for Parasitology, 1990, 20, 381-387.

Poirriez J., Justine J.L. \& Le PAPE P. Anguillules et anguillulose. Editions Techniques. Encyclopédie Médico-Chirurgicale (Paris, France), Maladies Infectieuses, 8-514-A-60, 1994, 8 p.

Reçu le 4 mai 2001

Accepté le 5 septembre 2001 